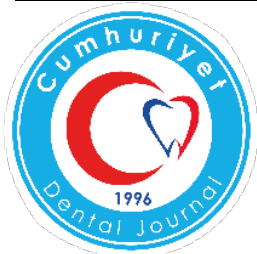

\title{
PYOGENIC GRANULOMA: A CASE REPORT
}

\author{
Piyojenik Granüloma: Olgu Raporu
}

\section{Ozgul CARTI ${ }^{1}$ Emine PIRIM GORGUN ${ }^{2}$ Fatih OZNURHAN ${ }^{1}$ Arife KAPDAN ${ }^{1}$}

\author{
Makale Kodu/Article Code $\quad$ : 148349 \\ Makale Gönderilme Tarihi $\quad: 23.10 .2015$ \\ Kabul Tarihi \\ $: 06.11 .2015$
}

\section{ABSTRACT}

Purpose: The purpose of this study is to evaluate the treatment and pursuit process of the pyogenic granuloma which has seen on 12 years old girl patient.

Case Presentation: Pyogenic granuloma is a lesion which classified in vascular tumors which constitute $30-60 \%$ of all the reactive lesions of gingival tissue. Trauma, infections of capillary wall, hormonal factors, foreign materials, hypertension and poor oral hygiene are accused for development of pyogenic granuloma. It may occur at all age groups and in both sexs. In the oral cavity, pyogenic granuloma lesions are most frequently encountered on the gingiva. Definitive diagnosis can only be made by histopathologic examination of biopsied tissue. The treatment of this lesion is surgical excision. If surgical excision removal is incomplete, the lesion has got the risk of the recurrence.

A twelve years old female child applied to our clinic with complaints like on anterior palatinal region gingival bleeding and swollen condition on the same region. As beginning treatment oral hygiene education was given to the patient and plaque and calculus were removed. Under local anesthesia the lesion was taken with excisional biopsy for doing distinctive diagnosis from the other pathological lesions which can be seen in oral cavity. In addition frenectomy surgery in the maxilla and ridge augmentation operation in the mandible is performed to provide more comfortable oral hygiene. Three-month follow-up results of the patients were found to occur again in the region of the palatal gingival enlargement. As a result, it was decided to re-operations performed gingivectomy. Patient after operations carried out gingivectomy was called to the appointment checked and encourage oral hygiene.

Conclusion: After taking of the excisional biopsy, the diagnose was made shaping "The Pyogenic Granuloma" to the mass which was examined histopathologically under the light microscope. In the control inspection, there was not any recurrence clinically.

Keywords: Pyogenic granuloma, excisional biopsy.

\section{ÖZ}

Amaç: Bu çalışmanın amacı, 12 yaşında bir kız çocuğunda görülen piyojenik granülomanın tedavisinin ve 12 aylık takip sürecinin değerlendirilmesidir.

Olgu bildirimi: Piyojenik granüloma vasküler tümörler içinde yer alan bir lezyondur. Gingivadaki bütün reaktif lezyonların \%30-60'ını teşkil eder. Piyojenik granülomanın gelişmesinde travma, damar duvarı enfeksiyonları, hormonal faktörler, yabancı cisimler, hipertansiyon ve zayıf oral hijyenin etken olduğu bildirilmektedir. Tüm yaş gruplarında ve her iki cinste de görülebilir. Oral kavite de piyojenik granüloma lezyonlarına en sık gingivada rastlanır. Kesin tanı sadece biyopsisi alınan dokunun histopatolojik incelenmesi ile konulabilir. Bu lezyonun tedavisi cerrahi eksizyondur. Yeterli bir cerrahi eksizyon yapılmazsa lezyonun tekrarlama riski vardır.

12 yaşındaki kız çocuğu üst çene anterior palatinal bölgesindeki dişetinde şişlik ve bu bölgede kanama şikayetleri ile kliniğimize başvurdu. Başlangıç tedavisi olarak hastaya oral hijyen eğitimi verildi, plak ve diş taşları uzaklaştırıldı. Lezyonun ağızda görülebilecek diğer patolojik oluşumlardan ayırıcı tanısını yapabilmek için lokal anestezi altında bisturi yardımıyla eksizyonel biyopsi ile alındı. Maksillada ek olarak frenektomi operasyonu, mandibulada ise oral hijyen koşullarını daha rahat sağlaması için vestibül derinleştirme operasyonu yapılmıştır. Hastanın üç aylık takibi sonucu palatinal bölgedeki dişeti büyümelerinin tekrar oluştuğu görülmüştür. Bunun sonucunda tekrar gingivektomi operasyonu gerçekleştirilmesine karar verilmiştir. Gerçekleştirilen gingivektomi operasyonu sonrasında hasta oral hijyen konusunda teşvik edilip kontrol randevularına çağrıldı.

Sonuç: Eksizyonel biyopsi sonrasında 1şık mikroskobu altında histopatolojik olarak incelenen kitleye "Piyojenik Granüloma" tanısı konuldu. Kontrol muayenesinde klinik olarak herhangi bir nüks mevcut değildi.

Anahtar Kelimeler: piyojenik granüloma, eksizyonel biyopsi

\footnotetext{
${ }^{1}$ Cumhuriyet University Faculty of Dentistry Department of Pediatric Dentistry, Sivas, Turkey.

${ }^{2}$ Cumhuriyet University Faculty of Dentistry Department of Periodontology, Sivas, Turkey.
} 


\section{INTRODUCTION}

Pyogenic Granuloma is a benign, nonneoplastic and mucocutaneous lesion that occurs in skin and mucous membranes. ${ }^{1,2}$ The first case of pyogenic granuloma was described in English literature by Hullien in $1884 .^{3} \mathrm{In}$ fact, the name "pyogenic granuloma" is a wrong description because no infection is present, no histological representation of granuloma as well. However it was thought to be an horse-borne mycotic infection, it has been found to be caused by inflammatory changes in benign oral tumors. ${ }^{4,5,6}$

When clinically examined, it appears as soft, smooth, lobulated, exophytic, red papule with or without pedicle. ${ }^{7,8}$ In second and third decades of the life it is encountered more frequently (3/2) in females than in males. ${ }^{9,10}$ It is generally believed that sex hormones in females play an important role in pathogenesis of the lesion. ${ }^{11}$ Low-degree local irritation, traumatic injury, hormonal factors and use of various drugs play roles in. ${ }^{12}$ Apart from that, local irritants such as dental calculi, foreign materials and poor oral hygiene are among triggering factors. ${ }^{7,13}$ In a study in which cases of 293 pyogenic granuloma was investigated, Gordon-Nunez et.al ${ }^{14}$ has stated that of the lesions; $83 \%$ on gums, $5.3 \%$ on lips and on tongue with same percentage, $4.2 \%$ on hard palate, $0.8 \%$ on buccal mucosa and $0.4 \%$ on floor of the mouth were found. Any radiological finding is present in granuloma. The definitive diagnosis is achieved by histological examination. ${ }^{15}$ Differential diagnosis is made with peripheral giant-cell granuloma, metastatic cancer, hemangioma, hyperplastic growth of gums, Kaposi sarcoma, angiosarcoma and non-hodgkin lymphoma. ${ }^{16}$ Treatment methods are surgical excision, electrocauterization, sclerotherapy, curettage, cryotherapy, laser application and keeping local irritants apart. $17,18,19,20$
Aim of this study is to evaluate the treatment and follow-up period of pyogenic granuloma found in a 12 year-old girl.

\section{CASE REPORT}

12 year-old female patient was admitted to department of pedodontics of Cumhuriyet University Faculty of Dentistry with complaints of swelling and bleeding in upper jaw palatine region. No extra-oral finding was detected in patient that was learned to be systemically healthy. Also, it has been learned that the swelling in palatine region was getting bigger during last month and she had complaint of bleeding during chewing. Lymphadenopathy, sign of infection or pain was not present.

In intraoral examination of the patient, swollen, pedunculated, partially ulcerated, hyperemic-looking and faint pink-colored mass with diameter of $13 \mathrm{~mm}$ was determined in supero-anterior palatine region.

In addition, oral hygiene of the patients is not proper and gums are hyperemic and edematous (Figure 1-2).

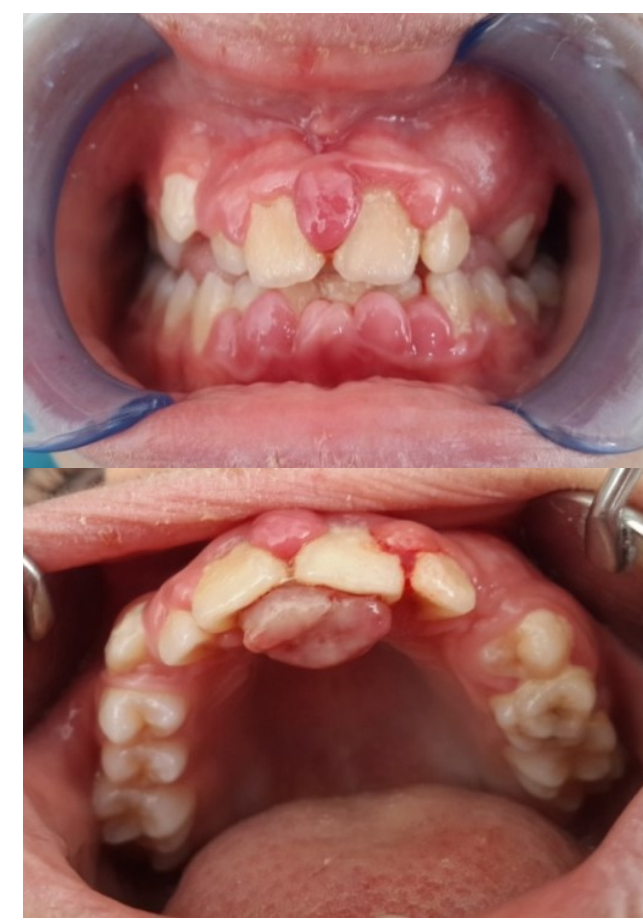

Figure 1. Initial clinical apperance 


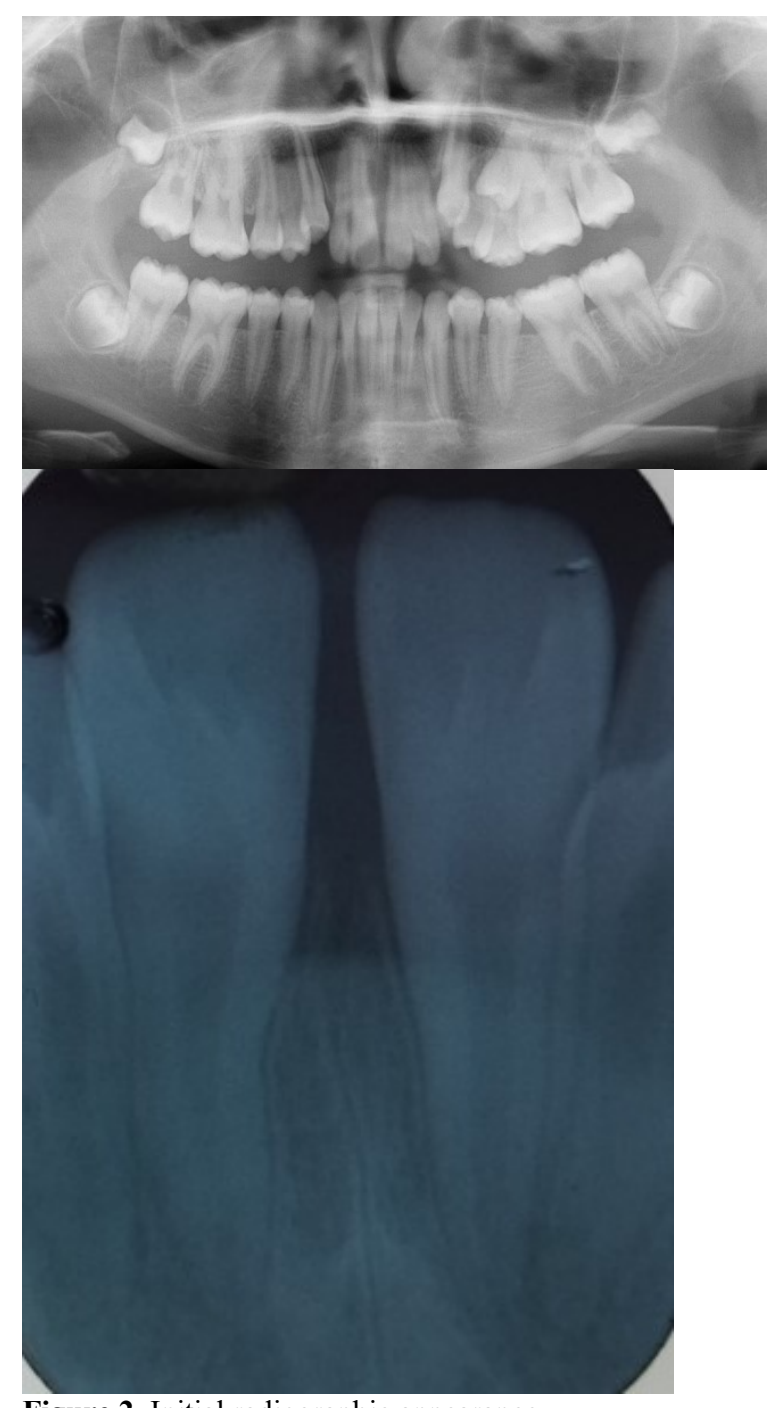

Figure 2. Initial radiographic appearance

\section{Periodontal and surgical approach}

For an initial treatment, especially dental plaques and calculi were scaled and oral hygiene education was told in order to achieve oral hygiene and to decrease gingival inflammation. After optimal oral hygienic conditions were achieved, the lesion located in supero-anterior region was removed with excisional surgery. Periodontal pat was inserted and kept for a week. Oral hygiene education was told to the patient. The patient was prescribed mouthwash containing $0.12 \%$ clorhexidine, an analgesic containing paracetamol and an antibiotic of amoxicillin type following the surgery (Figure 3).

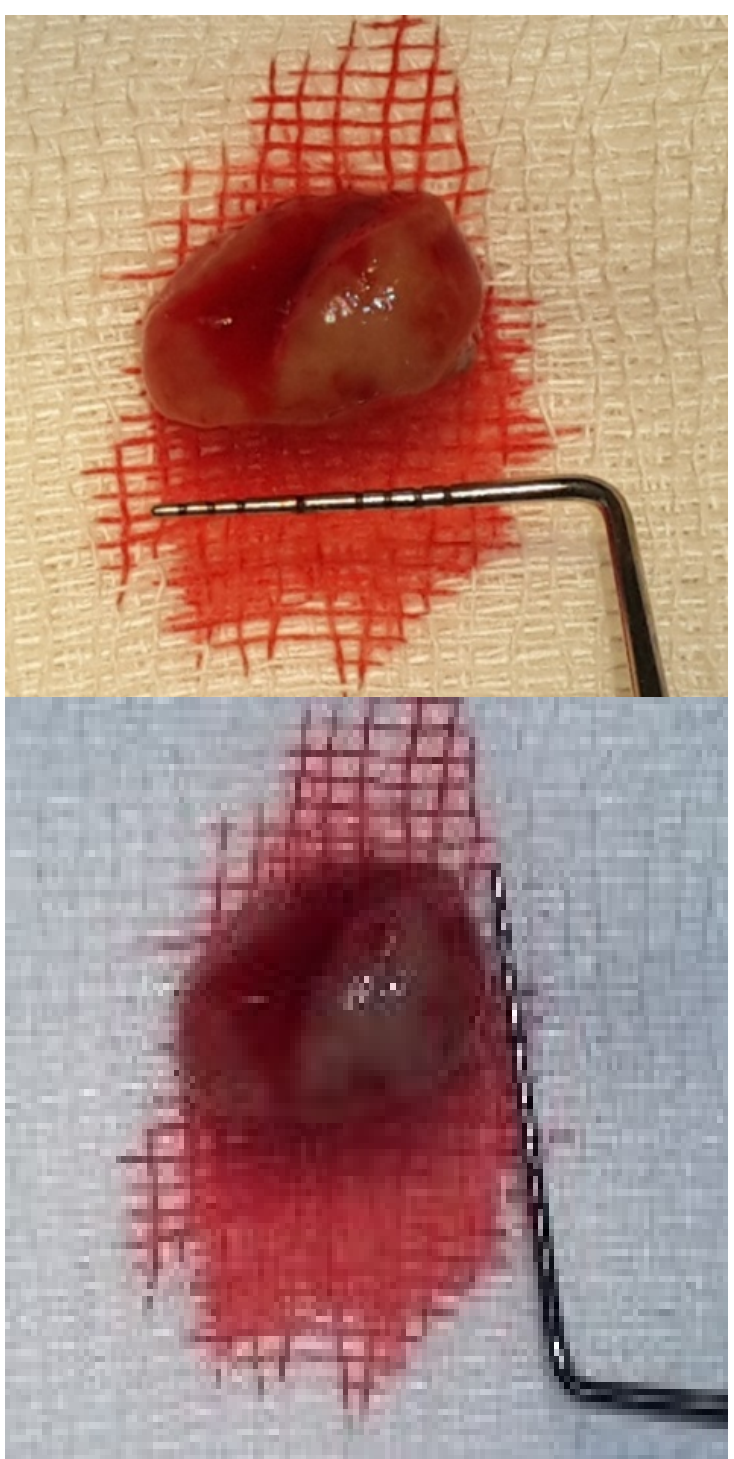

Figure 3. Excised mass

\section{Histopathological Evaluation}

The excised tissue sample was sent within $10 \%$ formalin solution for pathological examination. Biopsy sample was buried into paraffin after routine follow-up procedures and slices with thickness of $0,5 \mu$ was obtained by using microtome and examined under light microscope with Hematoxylin-eosin staining. In slices, a soft tissue demonstrating ulceratedlooking surface, proliferative vascular structures in stroma and dense mixture of cellular inflammatory infiltration sparsely have been determined (Figure 4-5). 


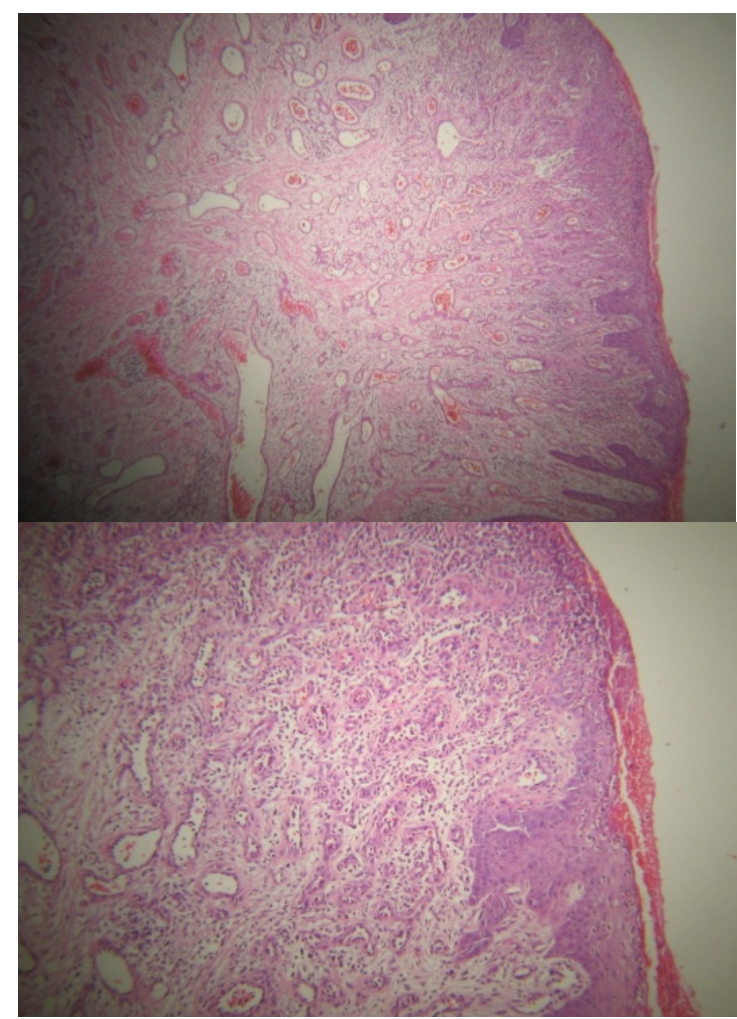

Figure 4. Histopathologic examination $\mathrm{a}: 4 \times 10$ magnification, b:10x10 magnification

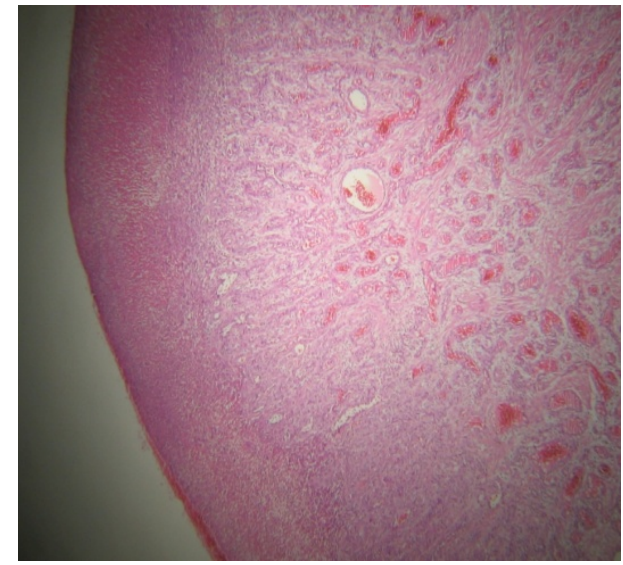

Figure 5. Histopathologic examination 4x10 Magnification

Stratified squamous epithelium is destroyed, ulcerated surface containing intraepithelial PMNL necrotic debris and peripheral blood elements, and intensive inflammatory granulation tissue have been determined. However in stroma, intensive capillary proliferation, increased vascularity, congestion in vessels (engorgement and blood pooling) are present.
On the surface squamous epithelium is completely destroyed and the surface is completely ulcerated. Collection of fibrin exudate has been intensively observed on ulcerated ground and more deeply intensive inflammatory granulation tissue and capillary proliferation have been observed. As a result of histopathological evaluation, the lesion was reported as pyogenic granuloma. One week after the operation, gingivectomy with internal bevel incision was performed in order to eliminate gingival swellings and tissue irregularities, granulation tissues are completely cleared. And additionally frenectomy in maxilla and vestibular enlargement operations in mandibula have been performed in order to patient to provide oral hygienic conditions more easily (Figure $6)$.

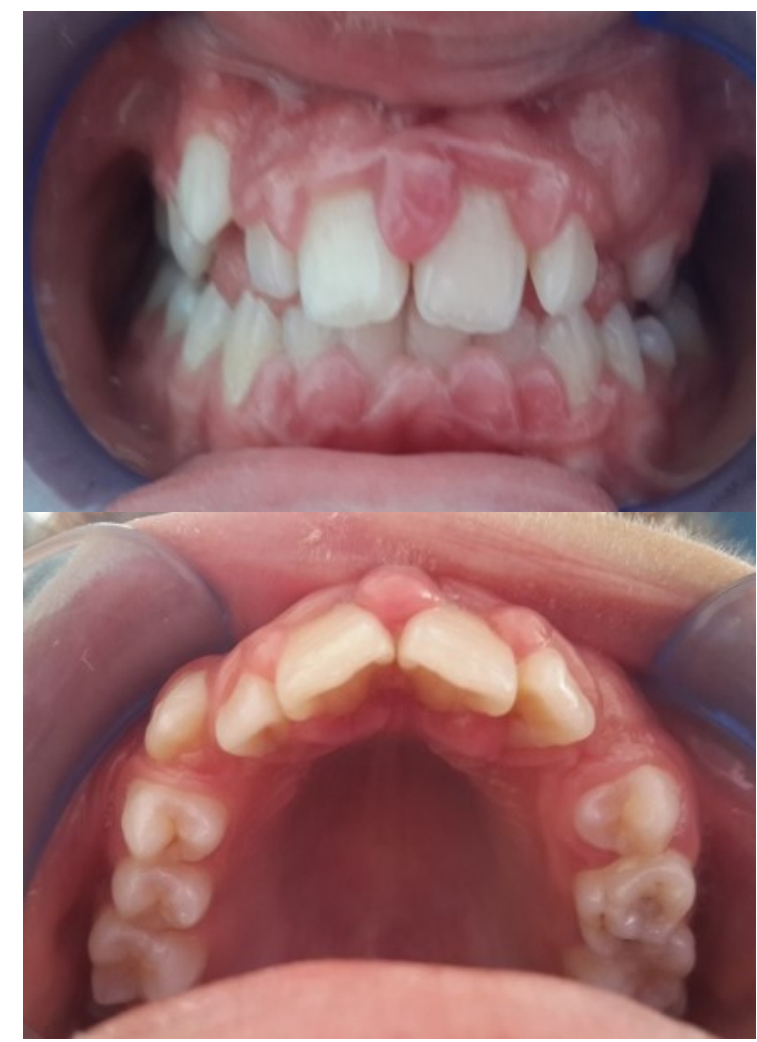

Figure 6. Clinical appearance after 1 week from the operation 
As a result of patient three-month controls, gingivectomy has been decided again for recurred inflammatory swellings in gums. One week after gingivectomy, patient was called for a control and informed again about oral hygiene and control sessions will be on going (Figure 7).

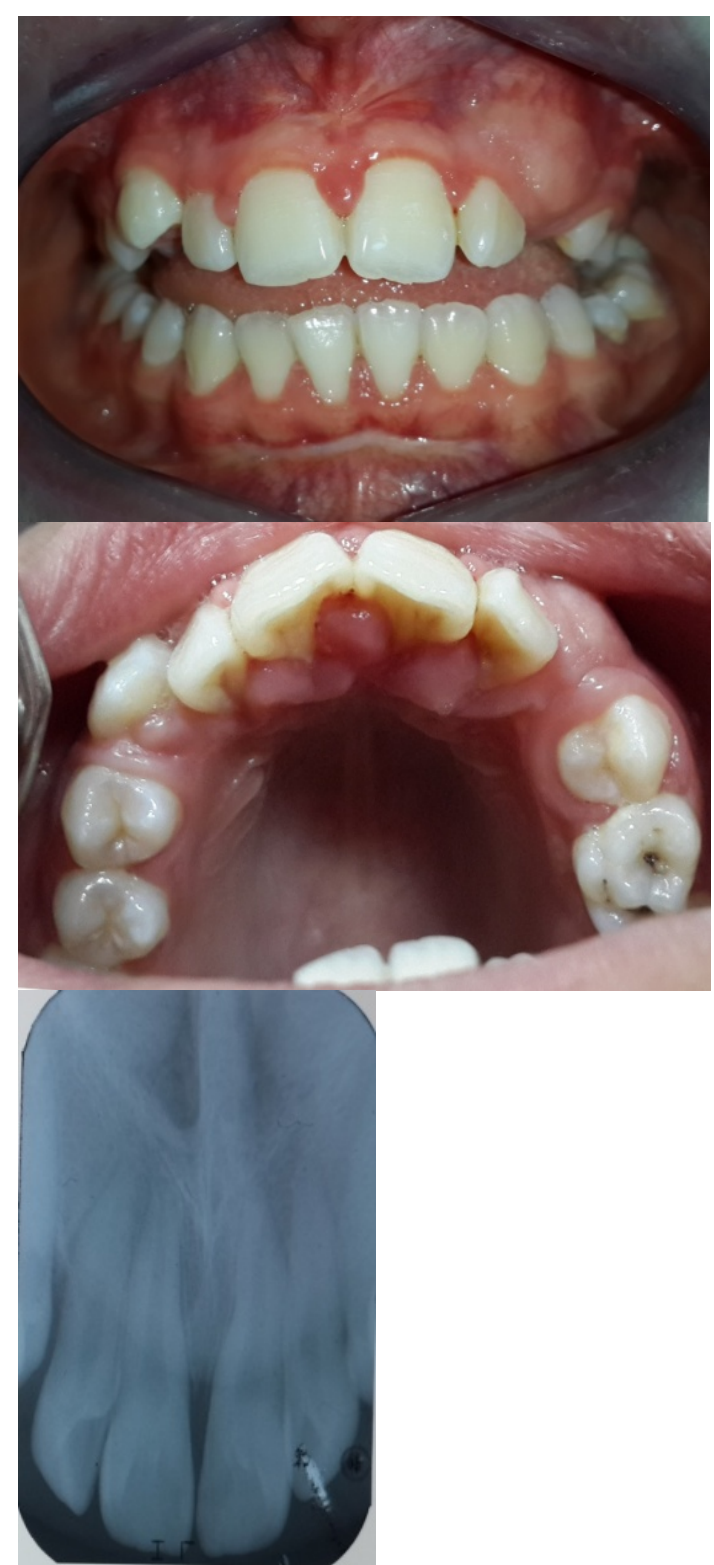

Figure 7. Clinical and radiological appearance 3 months after operation

In control appointment of the patient after 1 year, it was observed that gingival tissues were healthy with a successful recovery and there was no recurrence (Figure 8).
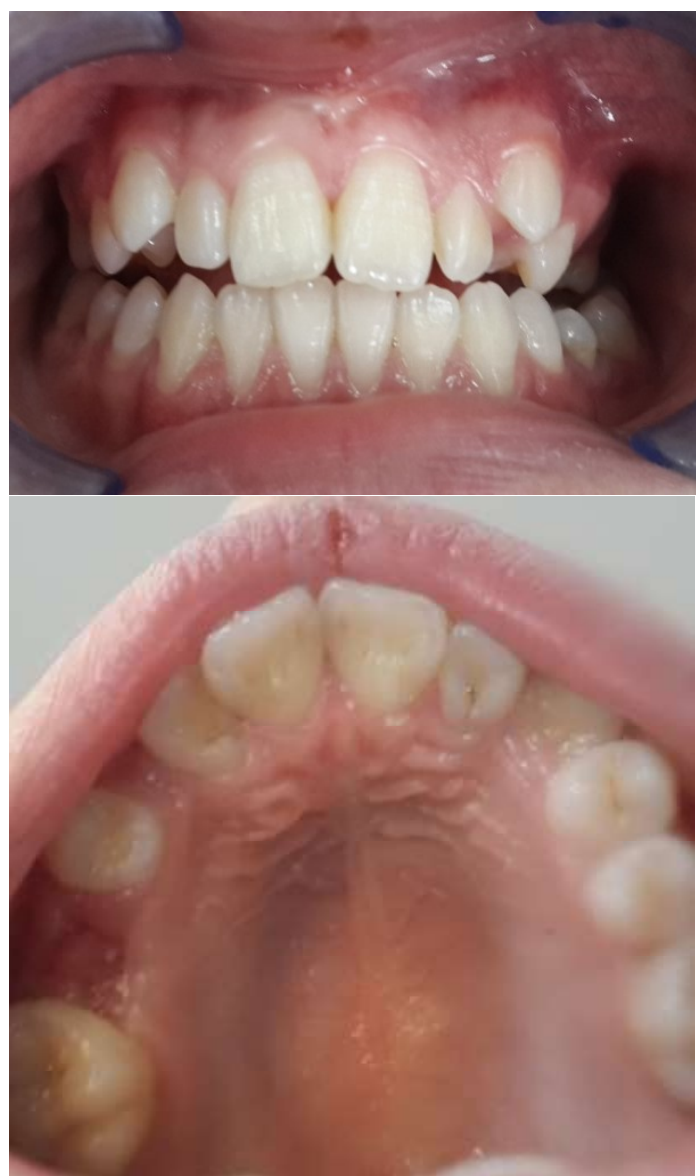

Figure 8. Clinical appearance of patient after 1 year

\section{DISCUSSION}

Oral Pyogenic Granuloma is a mucosal vascular hyperplasia affecting the tissues. ${ }^{21}$ It occurs due to respond of connective tissue to a minor injury or irritation. ${ }^{22}$ Irritating factors may be dental calculi, poor oral hygiene, nonspecific infections, excessive restorations and buccal biting. Due to irritation the underlying fibrovascular connective tissue becomes hyperplastic and granulation tissue that cause formation of Pyogenic Granuloma is formed. ${ }^{23}$ Due to high vascularity in the lesion, even a slight trauma can cause severe hemorrhages. Presence of obvious capillaries in newly-formed pyogenic granulomas and hyperplastic granulation tissue increases the probability of bleeding. Lesions tend to be more collagenized as the duration of stay increases. ${ }^{7}$ Colours of the lesions depend on duration of stay in mouth. Whereas newlyformed lesions vary from red to purple, lesions with long-term stay have pinkish coloration. In 
our case, swollen, pedunculated, partially ulcerated, hyperemic-looking and faint pinkcolored mass with diameter of $13 \mathrm{~mm}$ was determined in supero-anterior palatine region. Also it was learned that the patient had poor oral hygiene, and her gums were hyperemic and edematous.

Pyogenic Granuloma is commonly encountered in second decade of life. Especially in females due to effects of hormones on vessels it is the most commonly encountered in teenagers and young adults. ${ }^{24,25}$ Our case is a 12 year-old teenager female patient. We think that hormonal status during puberty plays important role in etiology.

Lesions are encountered more frequently in maxilla than in mandibula and anterior parts are more commonly affected than posterior parts. However pyogenic granuloma in oral cavity occurs most commonly in gingiva (in $75 \%$ of the cases) it may occur in lips, tongue, oral mucosa, hard palate, too. ${ }^{7,26}$ In our case, lesion has occurred in maxillary palatine region.

Incidence of Pyogenic Granuloma among all reactive oral lesions is found to be between $26.8-32 \%$. Clinically, these lesions are formed as a single nodule or unpedunculated papule and with smooth or lobulated surfaces. Their dimensions can vary from some $\mathrm{mm}$ to some $\mathrm{cm}$. Clinical progression is slow, asymptomatic and painless but it can also show a rapid progression. ${ }^{24,27}$ In our case, it has been learned that the swelling in palatine region has got bigger within last 1 month and he has had complaint of bleeding during chewing.

Histologically, the lesion demonstrates high vascular proliferation that resembles that of granulation tissue. ${ }^{7}$ Lesion contains smaller and larger blood vessels divided by a fibrotic septa. Definitive diagnosis concerning Pyogenic Granuloma is achieved by presence of polymorphic and chronic inflammatory cells along the edematous stroma and microcyst formation. ${ }^{28}$ In our case, in slices, a soft tissue demonstrating ulcerated-looking surface, proliferative vascular structures in stroma and dense mixture of cellular inflammatory infiltration sparsely have been determined. Stratified squamous epithelium is destroyed, ulcerated surface containing intraepithelial PMNL necrotic debris and peripheral blood elements, and intensive inflammatory granulation tissue has been determined. However in stroma, intensive capillary proliferation, increased vascularity, congestion in vessels (engorgement and blood pooling) are present. Intense inflammatory infiltration is found around the vessels.

Treatment of Pyogenic Granuloma is based on removal of the lesion. Treatment of Pyogenic Granuloma depends on size and location of the lesion. Excisional biopsy is the treatment option in majority of cases but other treatment options can be thought. Larger lesions are treated with incisional biopsy in order to prevent deformity. Neodymium: Yttrium Aluminum: Garnet (Nd: YAG) laser surgery can be used in excision of the lesion due to its superior coagulative ability and its ability to cause less intraoperative bleeding. Other alternative treatment options are cryotherapy, electrocauterization, pulsed dye laser and chemical agents. ${ }^{29,}{ }^{30}$ In our case, The lesion was removed with excisional surgery. Gingivectomy was performed in order to eliminate gingival tissue irregularities, and frenectomy in maxilla and vestibular enlargement operations in mandibula have been performed in order to patient to provide oral hygienic conditions more easily.

Because of being an encapsulated lesion the pyogenic granulomas can reoccur if they are not completely removed. Whereas in excision involving the floor of the lesion and the periosteum and in removal performed with full-thickness flaps recurrence does not occur, in application of electrocauterization in which lesion is removed superficially, this ratio is 
$43.5 \% .{ }^{31}$ When pulsed dye laser is used this ratio is $9 \% .{ }^{32}$ Whereas in electrocauterization following excision that performed on 128 cases by Paglia and Kohen recurrence is not encountered, in the study in which Lee et.al. used $\mathrm{CO}_{2}$ laser 2 unsuccessful cases were reported. ${ }^{33,34}$ In the study conducted by Krisnapillai et.al recurrence was reported in $14.88 \%$ of 215 cases. ${ }^{35}$ During postoperative period patient follow-up should be performed precisely and all dental calculi in area of the lesion and neighboring areas against possibility of recurrence, possibility of recurrence should be tried to be decreased by removal of periosteum and bone in the localized area and educating the patient about oral hygiene. In our case, in the control after 3 months, recurrence found in palatine region was removed by gingivectomy again.

In conclusion, it should be remembered that pyogenic granulomas can develop rapidly and possibility of recurrence following the treatment is present. It shouldn't be forgotten that even after an effective treatment following the definitive clinical and histological diagnosis of Pyogenic Granuloma recurrence may occur and the patient should be followed-up.

\section{REFERENCES}

1. Jafarzadeh $H$, Sanatkhani $M$, Mohtasham N. Oral pyogenic granuloma: a review. J Oral Sci 2006;48:167-75.

2. Ramirez. K, Bruce G, Carpenter W. Pyogenic granuloma: case report in a 9-yearold girl. General Dentistry. 2002;50 (3):280-81.

3. Hullihen SP. Case of aneurism by anastomosis of the superior maxillae. Am $\mathrm{J}$ Dent Sci 1844;4:160-2.

4. Yaan K, Jin YT, Lin MT. Expression of Tie2, angiopoietin-1, angiopoietin-2, ephrin B2 and Eph B4 in pyogenic granuloma of human gingival implicates their role in inflammatory angiogenesis. J Periodontal Res 2001; 35: 165.
5. Angelopulos AP. Pyogenic granuloma of the oral cavity: Statistical Analysis of its clinical features. J Oral Surg 1971; 29: 890.

6. Lever VF, Lever GS. Histopathology of the skin. 13. Lpincolt Co, 1990: 698.

7. Neville BW, Damm DD, Allen CM, et al. Oral \& maxillofacial pathology. 2nd edn. Philadelphia: WB Saunders, 2002:437-95.

8. Eversole LR. Clinical outline of oral pathology: diagnosis and treatment. 3rd edn. Hamilton: BC Decker, 2002:113-14.

9. Aguilo L. Pyogenic granuloma subsequent to injury of primary tooth: a case report. Int J Paed Dent 2002;12:438-41.

10. Shenoy SS, Dinkar AD. Pyogenic granuloma associated with bone loss in an eight-year-old child: a case report. J Indian Soc Pedod Prev Dent 2006;24:201-3.

11.Bhaskar SN, Jacoway JR. Pyogenic granulom: clinical features, incidence, histology, and result of treatment: report of 242 cases. J Oral Surg 1966; 245: 391-8.

12.Al-Khateeb T, Ababneh K. Oral pyogenic granuloma in Jordanians: a retrospective analysis of 108 cases. J Oral Maxillofac Surg 2003;61:1285-8.

13.Regezi JA, Sciubba JJ, Jordan RC. Oral Pathology: Clinical Pathological Considerations. 4th ed. Philadelphia: WB Saunders; 2003. p. 115-6.

14.Gordón-Núñez MA, de Vasconcelos Carvalho M, Benevenuto TG, Lopes MF, Silva LM, Galvão HC. Oral pyogenic granuloma: a retrospective analysis of 293 cases in a Brazilian population. J Oral Maxillofac Surg 2010;68:2185-8.

15.Jafarzadeh H, Sanatkhani M, Moshtasham N. Oral pyogenic granuloma: a review. J Oral Sci 2006;48:167-75.

16. Sills ES,Zegarelli DJ, Hoschander MM, Strider WE. Clinical diagnosis and management of hormonally responsive oral pregnancy tumor (pyogenic granuloma). J Reprod Med 1996;41:467-70. 
17. Fowler EB, Cuenin MF, Thompson SH, Kudryk VL, Billman MA. Pyogenic granuloma associated with guided tissue regeneration: a case report. J Periodontol 1996; 67: 1011-5.

18. Wandera A, Walker PO. Bilateral pyogenic granuloma of the tongue in graft-versus-host disease: report of case. ASDC J Dent Child 1994; 61: 401-3.

19. Anderson WAD, Scatti MT. Skin. In Synopsiss of Pathology. Cv Mosby Co. 1980: 681.

20.Davies MG, Marks R. Dermo-epidermal relationships in pyogenic granulomata. $\mathrm{Br} \mathrm{J}$ Dermatol 1978; 99: 503-12.

21.Jafarzadeh H, Sanatkhani M, Mohtasham N. Oral pyogenic granuloma: a review. J Oral Sci 2006; 48(4): 167-75.

22. Mathur LK, Bhalodi AP, Manohar B, Bhatia A, Rai N, Mathur A. Focal fibrous hyperplasia: a case report. Int $\mathrm{J}$ Dent $\mathrm{Clin}$ 2010; 2(4):6-7.

23.Kerr DA. Granuloma pyogenicum. Oral Surg Oral Med Oral Pathol 1951; 42: 158.

24.Ramirez. K, Bruce G, Carpenter W. Pyogenic granuloma: case report in a 9-yearold girl. General Dentistry. 2002;50:280-81.

25.Karthikeya P, Mahima VG, Lahari K. Exragingival pyogenic granuloma. Indian $\mathrm{J}$ Dent Res. 2006;17:199-202.

26. Graham RM. Pyogenic granuloma: an unusual presentation. Dent Update. 1996;23:240-41.

27.Jafarzadeh H, Sanatkhani M, Mohtasham N. Oral pyogenic granuloma: a review. J Oral Sci. 2006;48:167-75.

28. Greenberg MS, Glick M. Burket's oral medicine: diagnosis and treatment. 10th edn. Hamilton: BC Decker, 2003:141-2.
29. Ichimiya M, Yoshikawa $Y$, Hamamoto $Y$, et al. Successful treatment of pyogenic granuloma with injection of absolute ethanol. J Dermatol 2004;31:342-4.

30.Moon SE, Hwang EJ, Cho KH. Treatment of pyogenic granuloma by sodium tetradecyl sulfate sclerotherapy. Arch Dermatol 2005;141:644-6.

31.Patrice SJ, Wiss K, Mulliken JB. Pyogenic granuloma (lobular capillary hemangioma): a clinicopathologic study of 178 cases. Pediatr Dermatol 1991, 8: 267-276

32.Tay Y-K, Weston WL, Morelli JG. Treatment of pyogenic granuloma in children with the flashlamp-pumped pulsed dye lazer. Pediatrics 1997;99:368-70.

33.Pagliai KA, Cohen BA. Pyogenic granuloma in children. Pediatr Dermatol 2004, 21: 10-3.

34.Lee CT, Tham SN, Tan T. inst>al experience with $\mathrm{CO} 2$ laser in treating dermatological conditions. Ann Acad Med Singapore 1987;16: 713-5.

35.Krishnapillai R, Punnoose K, Angadi PV, Koneru A. Oral pyogenic granuloma-a review of 215 cases in a South Indian Teaching Hospital, Karnataka, over a period of 20 years. Oral Maxillofac Surg 2012;16:305-9.

\section{Corresponding Author Address:}

Özgül CARTI

Cumhuriyet Üniversitesi

Diş Hekimliği Fakültesi

Pedodonti Anabilim Dalı

58140, Kampüs/ SIVAS

Tel: 00 90.346.2191010/3103

Faks: 00 00.346.2191237

E-mail: ozgulcarti@hotmail.com 